\title{
Macro-level drivers of multidimensional poverty in sub-Saharan Africa: Explaining change in the Human Poverty Index
}

\author{
Author: \\ Heath Prince ${ }^{1}$ \\ Affiliation: \\ ${ }^{1}$ University of Texas, Austin, \\ United States \\ Correspondence to: \\ Heath Prince \\ Email: \\ heathprince@ \\ raymarshallcenter.org \\ Postal address: \\ 6636 West William Cannon \\ Dr., Apt. 1422, Austin, \\ TX 78735, United States

\section{Dates:} \\ Received: 18 Apr. 2014 \\ Accepted: 16 Sept. 2014 \\ Published: 18 Dec. 2014

\section{How to cite this article:} \\ Prince, H., 2014, 'Macro-level \\ drivers of multidimensional \\ poverty in sub-Saharan \\ Africa: Explaining change in \\ the Human Poverty Index', \\ African Evaluation Journal \\ 2(1), Art. \#73, 11 pages. \\ http://dx.doi.org/10.4102/ \\ aej.v2i1.73
}

\section{Note:}

The paper was presented at the 7th African Evaluation Association (AfrEA) conference held in Yaounde, Cameroon, 1-5 March 2014.

\section{Copyright:}

(C) 2014. The Authors.

Licensee: AOSIS

OpenJournals. This work is licensed under the Creative Commons Attribution License.
Poverty is increasingly recognised as a multidimensional phenomenon in the development literature, encompassing not only income, but also a range of factors related to broadening an individual's freedoms to live a life of their own choosing. Poverty so understood suggests that alternative approaches to poverty measurement reflecting this multidimensionality may point towards alternative policies for poverty alleviation. The imperative to reinforce pro-poor policy development in sub-Saharan Africa with evaluation findings that reflect improvements in well-being, rather than solely improvements in national economies, has become self-evident as, despite decades of market-led development policies, much of the subcontinent remains mired in deprivation. As recognised by the 2014 African Evaluation Association's biannual conference, fresh thinking and new evaluation metrics are required in order to create policies that more effectively increase well-being. This article explores the factors that may account for changes in one metric of multidimensional poverty in developing countries, the United Nation Development Program's Human Poverty Index (HPI), and will be primarily concerned with measuring the effects on the HPI of policies and activities that relate to, or are explicitly meant to encourage, economic growth, increased literacy and improved health. The study focuses on the outcomes of a panel data set, created for the purpose of this study, of HPI scores for a set of 47 sub-Saharan countries, between 1990 and 2010, and a range of indicators that the development literature and theory suggest should have an effect on income poverty, asking, what is the relationship between these indicators and multidimensional poverty? A parallel set of models has been developed to measure the response of household consumption expenditure to changes in economic growth and human capabilities indicators. All models are estimated using fixed effects estimators and cluster robust standard errors in Stata 12. Consistent with the development literature, household expenditure appears to be significantly and positively related to changes in gross domestic product (GDP) per capita. However, when the HPI is regressed on GDP per capita, no statistically significant relationship is observed, even when controlling for a range of other indicators, calling into question the relationship between economic growth and well-being in much of sub-Saharan Africa. This finding suggests that development policies that focus primarily on economic growth as a means to addressing multidimensional deprivation may be misplaced.

De plus en plus, la pauvreté est reconnue comme un phénomène multidimensionnel dans les publications relatives au développement, englobant non seulement le revenu, mais aussi une gamme de facteurs liés à l'élargissement des libertés d'un individu de vivre la vie de son choix. La pauvreté ainsi comprise suggère que les approches alternatives à la mesure de la pauvreté prenant en compte cette multidimensionnalité peuvent inspirer des politiques alternatives pour réduire la pauvreté. L'impératif de renforcement du développement de la politique en faveur des pauvres en Afrique subsaharienne avec des conclusions d'évaluations reflétant des améliorations du bien-être, et non pas uniquement des améliorations des économies nationales, est devenu évident puisque, malgré des décennies de politiques de développement orientées vers le marché, une grande part du sous-continent reste embourbée dans le dénuement. Comme l'a reconnu la conférence semestrielle de l'African Evaluation Association (Association africaine d'évaluation) 2014, une nouvelle réflexion et de nouveaux paramètres d'évaluation sont requis afin de créer des politiques qui améliorent plus efficacement le bien-être. Cet article étudie les facteurs qui peuvent être pris en compte en vue de modifications d'un indicateur de pauvreté multidimensionnel dans les pays en développement, l'Indicateur de Pauvreté Humaine (IPH) du Programme des Nation Unies pour le Développement, et se préoccupera principalement de mesurer les effets sur l'IPH de politiques et d'activités qui se lient à la croissance économique, l'alphabétisation accrue et une meilleure santé ou sont explicitement destinées à encourager ces derniers. L'étude se concentre sur les résultats d'un ensemble de données de panel, créées aux fins de cette étude, de scores d'IPH pour un ensemble de 47 pays d'Afrique sub-saharienne, entre 1990 et 2010, et d'une gamme d'indicateurs dont l'effet sur la pauvreté de revenu est suggéré par la littérature et la théorie du développement, en se posant la question suivante : Quelle est la relation entre ces indicateurs et la pauvreté multidimensionnelle ? Un ensemble parallèle de modèles a été développé afin de mesurer la réponse des dépenses de consommation des ménages aux changements de la croissance économique et des indicateurs de capacités humaines. Tous les modèles sont estimés en utilisant des estimateurs à effets fixes et des erreurs-types robustes en grappes dans Stata 12. Conformément aux écrits sur le développement, les dépenses des ménages semblent être significativement et positivement corrélées aux variations du produit intérieur brut (PIB) par habitant. Toutefois, lorsque l'IPH est calculé par régression en fonction du PIB par habitant, aucune relation statistiquement significative n'est observée, même après contrôle d'une gamme d'autres indicateurs, remettant en question la relation entre la croissance économique et le bien-être dans une grande partie de l'Afrique subsaharienne. Cette découverte suggère que les politiques de développement qui s'axent principalement sur la croissance économique comme moyen de traiter la privation multidimensionnelle peuvent se fourvoyer. 


\section{Introduction}

It is often said that what gets measured is what gets done, and for the bulk of the international development field's history, poverty has been expressed and measured in monetary terms, such as gross domestic product (GDP) per capita, when discussed at a national or global scale, or the $\$ 1.25$ (plus periodic adjustments) per day standard commonly cited in the development literature, when discussed at the individual level. Because poverty is conceptualised as primarily a function of control over monetary resources, policies designed to reduce poverty and improve well-being have tended to focus primarily on economic growth and the expansion of monetary wealth in the developing world.

However, the debate over the appropriate metrics for measuring poverty at a national level has begun to bubble over, leading to the proliferation of multidimensional metrics of poverty that aim to better represent the various components of deprivation. Proponents of these multidimensional poverty indices argue that a change in metrics from unidimensional, monetary-based metrics to multidimensional metrics is critical for the creation of effective international development policy (Alkire \& Foster 2011; Anand \& Sen 1997; Arimah 2004; Fleurbaey 2009; Kakwani \& Silber 2008; Stiglitz, Sen \& Fitoussi 2009; Ul Haq 1995).

These multidimensional poverty indices are designed to look beyond monetary-based metrics of development and to identify indicators that better explain how people, rather than economies, are developing. However, properly explaining poverty is, by itself, largely an academic exercise. The point of research on the topic should be to change policy in order to improve the effectiveness of poverty interventions. Underscoring the importance of the connection between sound measurements of social welfare and the policies meant to address them, Fleurbaey (2009:1030) notes:

The practical importance of a measure of social welfare can hardly be overstated. Policy decisions, cost-benefit analysis, international comparisons, measures of growth, and inequality studies constantly refer to evaluations of individual and collective well-being. The fact that monetary measures still predominate in all such contexts is usually interpreted as imposed by the lack of a better index rather than reflecting a positive consensus. (emphasis added)

The primary concern of this study is accounting for poverty reduction or increase in sub-Saharan Africa, as measured by the United Nation Development Program's (UNDP) former metric for aggregate, national-level deprivation, the Human Poverty Index (HPI). The HPI was designed to tell a different story than the UNDP's Human Development Index (HDI). The HPI value reflects the proportion of people affected by any one of three key deprivations - adult illiteracy, death before age 40 and a composite measure of the percentage of children underweight for their age and the percentage of a population who lack access to clean water - providing a comparative, multidimensional measure of the prevalence of human poverty (UNDP 2008). Where the HDI measures human development, the HPI measures deprivation; where the HDI examines the progress of a society, the HPI measures the percentage of people left out of this progress.

The HPI is a broad, aggregate measure of how well the poorest of the poor are faring in a given country. Whilst it can be argued that the selection of indicators that comprise the HPI (or any similar multidimensional index) is arbitrary (Alkire \& Santos 2009; Basarir 2011; Berenger \& Verdier-Chouchane 2007; Ravallion 1992), it would be difficult to argue that these indicators are not metrics of deprivation, or that they are not indicators that are typically used to characterise extreme poverty.

This study is an exploration of those factors that appear to contribute to changes in the HPI and will be primarily concerned with policies and activities that relate to, or are explicitly meant to encourage, economic growth, increased literacy and improved health. In order to draw out the distinctions between factors that drive change in a measure of multidimensional deprivation and those that drive change in unidimensional and income-based metrics of poverty, I will use fixed effects panel models that regress the HPI on various factors reported to reduce income poverty and compare these findings to similar models that regress final household consumption expenditure per capita on those same factors.

The models developed for this study are designed to answer three primary research questions:

- To what degree do economic growth-based policies affect levels of deprivation in developing countries, as measured by the HPI?

- To what degree do human capabilities-based policies affect the HPI in developing countries?

In addition, a related, and perhaps unavoidable, research question has to do with the comparison between how economic growth and human capabilities development strategies relate to a metric of multidimensional poverty and how they relate to a monetary-based metric of poverty, in this case household final consumption expenditure per capita. If one assumes that a monetary-based metric of poverty is an inadequate measurement of human deprivation, then it would be useful to examine how factors that drive change in multidimensional poverty differ, if at all, from those that drive change in monetary-based metrics. This leads to a third research question:

- How do factors that drive change in household final consumption expenditure per capita differ from those that drive change in the HPI?

\section{Theoretical framework}

Whilst the rationale for monetary-based measures of poverty has been evolving since the early part of the 20th century and is extensively covered in the literature (Atkinson 1987; Coudouel, Hentschel \& Wodon 2002; Ravallion 1992; 
Ravallion in Anand, Segal \& Stiglitz 2010), arguments for multidimensional poverty metrics have only relatively recently reemerged in the literature. Whilst not yet as welldeveloped as the literature on monetary-based metrics, the literature on alternative methods for measuring development has significantly expanded in recent years.

However, gaps in the literature exist when, instead of examinations of the relationship between monetary-based metrics of poverty and development policies, the relationship between multidimensional metrics and development policies is considered.

Ravallion (1992) draws out the link between measurement and policy by arguing that it is essential that a country's progress towards reducing poverty be reliably measured in order for international financial institutions, regional development banks and bilateral aid agencies 'to have reasonable confidence about the impacts of policy initiatives and reforms on the poor' (p. vii).

Whilst one of the primary objectives of international financial institutions, regional development banks and bilateral aid agencies is to either directly or indirectly reduce the incidence of poverty and improve well-being, the starting point for most of these institutions is a conceptualisation of poverty as seen through the lens of mainstream economic theory, which, to the extent that it addresses it at all, defines poverty as, primarily, insufficient income or command over resources. The policy prescriptions that flow from this formulation are coherent and consistent with this understanding of the root causes of deprivation, particularly as it manifests in the developing world.

This concatenation of neoclassical economic theory and the policies implemented by donor countries and international financial institutions forms a specific international development regime, one that emphasises economic growth, the generation of wealth and the distribution of that wealth for the purposes of improving well-being.

Dasgupta (1993) neatly summarises the two primary contending positions regarding the measurement of wellbeing and the link between national accounts, such as GDP per capita, and poverty measurement:

If we wish to estimate changes in social well-being, there are two routes available. The first is the direct one. The idea is to measure changes in the constituents of well-being, such as health, longevity, basic liberties, literacy, and also real income, as indicators of the extent of commodity choice. In so doing, we measure changes in well-being itself. ... The other route is roundabout. It is to measure changes in the value of the determinants of well-being. Since commodities are inputs in the production of well-being, we measure changes in the accounting (or shadow) values of goods and services. In short, the idea is to measure changes in real national income. (p. 184)

With nearly 300 citations in other studies, and as recently as May 2012 (according to a search of the Web of Science database on 01 July 2012), David Dollar and Aart Kraay's (2003) study, 'Growth is good for the poor', has proven to be one of the more influential, and contentious, regarding the connection between policies that spur economic growth and income poverty. In it, Dollar and Kraay define the poor as those in the bottom quintile of the income distribution of a country and set about empirically examining the relationship between growth in average incomes of the poor and growth in overall incomes, using a large sample of developing and developed countries between the 1960s and 1990s. Dollar and Kraay (2003:3) report that they find that 'on average incomes of the poor rise equiproportionately with average incomes' and conclude that 'a basic policy package of private property rights, fiscal discipline, macroeconomic stability, and openness to trade on average increases the income of the poor to the same extent that it increases the income of the other households in society' (p. 27).

The charts in Figure 1 and Figure 2 indicate that, in some cases, not only consumption, but also multidimensional poverty behave as Dollar and Kraay would have predicted income poverty to behave. For several sub-Saharan countries, GDP per capita growth moved in tandem with household consumption (but appears to have been preceded

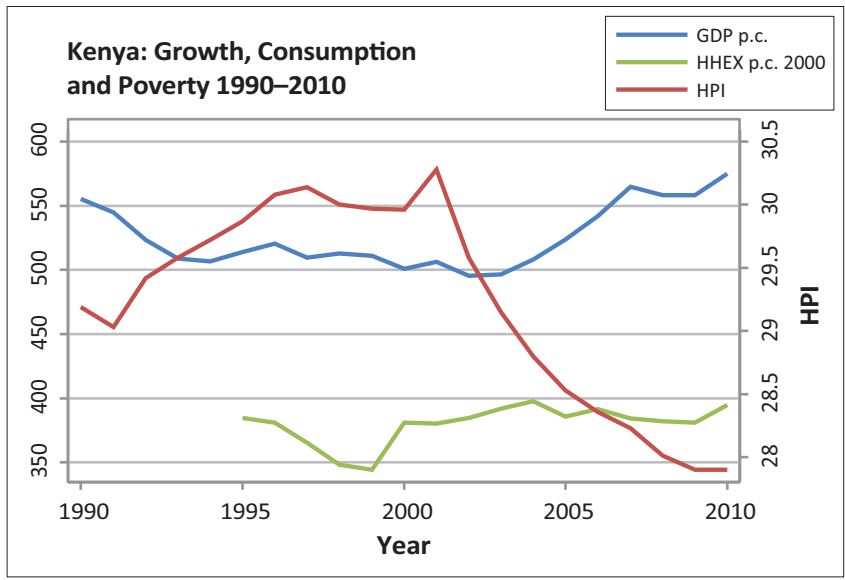

HPI, Human Poverty Index.

FIGURE 1: Kenya growth, consumption and poverty 1990-2010.

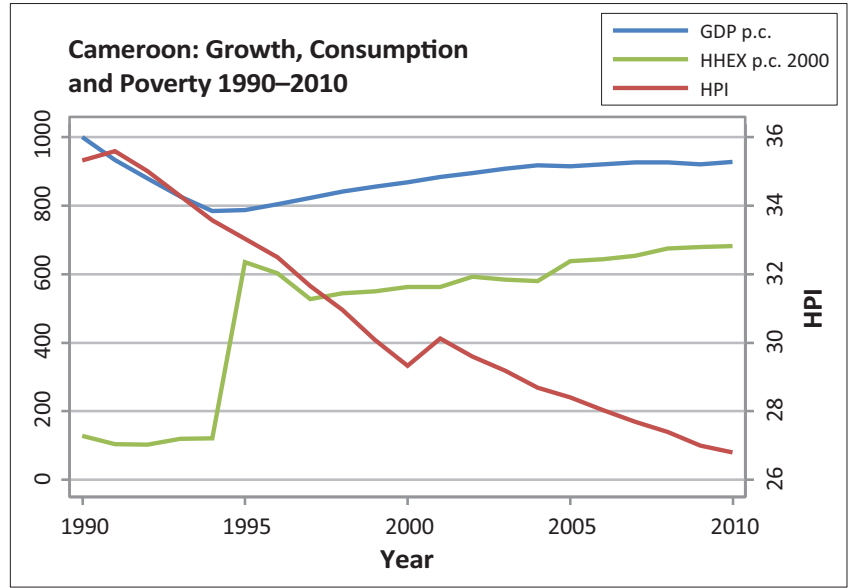

FIGURE 2: Cameroon growth, consumption and poverty 1990-2010. 


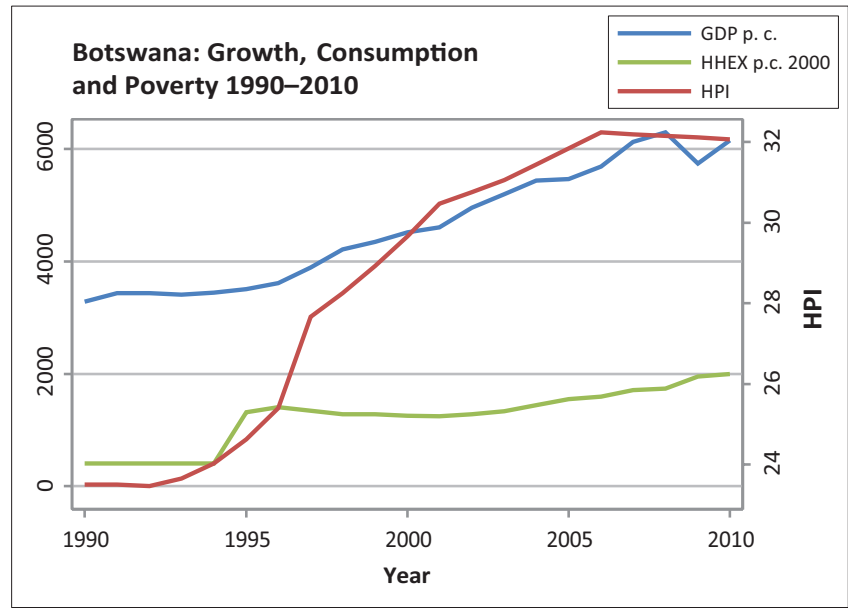

FIGURE 3: Botswana growth, consumption and poverty 1990-2010.

by reductions in multidimensional poverty, as predicted by Ranis, Stewart \& Samman 2006). This relationship is illustrated in Figure 1 and Figure 2 by Kenya and Cameroon, but a similar story could be told for others, including Rwanda and Mauritius.

A somewhat different, and more common, picture emerges from the data of countries such as Botswana (Figure 3). In these countries, despite steady growth in GDP per capita over the 21-year period of the study, multidimensional poverty also increases.

When the region as a whole is considered (Figure 4), growth in GDP per capita is followed by only marginal reductions in multidimensional poverty, but also by a small decline in average household consumption expenditure beginning in 1993.

A rejection of well-being and deprivation as concepts reducible to a measure of income, partly illustrated by the graphs above, is reflected in Sudhir Anand and Amartya Sen's (1997) rationale for creating the HPI. In describing the motivation behind the HPI, Anand and Sen argued that the measurement of development had too long focused on the 'conglomerative perspective', a perspective that makes no distinction between the well-off and the deprived. Instead, Anand and Sen proposed that development be measured from a 'deprivation perspective', in which the concern of development is focused specifically on the deprived. By measuring development in this way, Anand and Sen argue that 'lack of progress in reducing the disadvantages of the deprived cannot be "washed away" by large advances - no matter how large - made by the better off people' (Anand \& Sen 1997):

'Both the HPI and the income-poverty indicators share the deprivational perspective, but while the latter see nothing in poverty other than the low-ness of incomes, the HPI must take a much broader view, in line with the approach of human development. It would, in fact, be useful to see how the values and rankings of HPI relate to the results of income-based poverty analysis.' (p. 1, emphasis added)

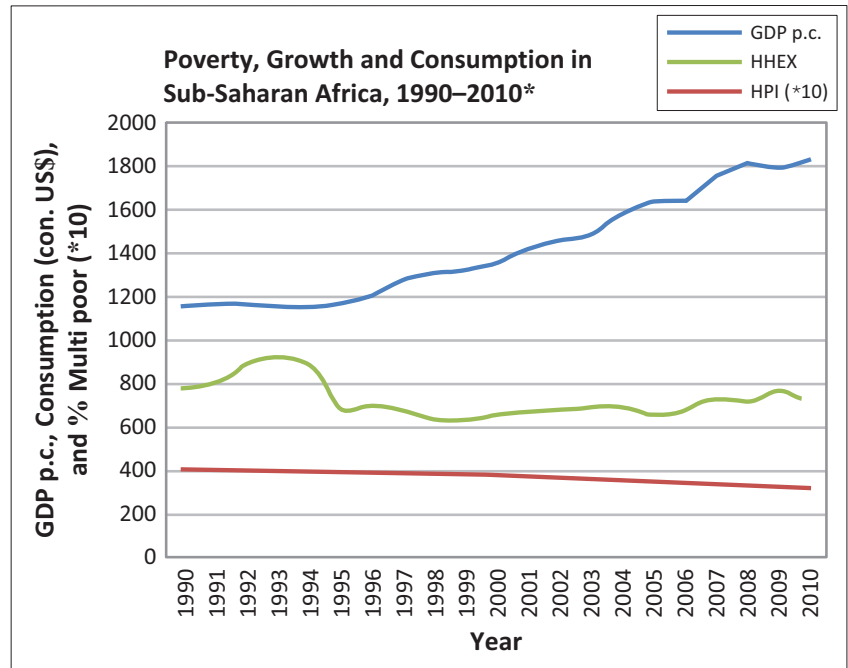

*, Author's calculations.

FIGURE 4: Growth, Consumption and Poverty in sub-Saharan Africa, 1990-2010.

Unlike measures of individual or household poverty, the HPI is an aggregate measure of societal deprivation. Unlike the Multidimensional Poverty Index (MPI), which succeeded the HPI as the UNDP's metric of deprivation, the HPI is not easily decomposed by geographic area, ethnicity or other characteristic, but, instead, aims to provide an overarching assessment of a given country's ability to provide for its poorest.

Introduced in the UNDP's (1997) Human Development Report, the HPI remained essentially true to its original formulation ${ }^{1}$ until it was replaced in 2010 by the MPI, making possible the comparative analysis to which Anand and Sen (1997) refer, as well as an analysis of how the HPI responds over time to various factors.

\section{Human Poverty Index formula}

$H P I=\left[\frac{1}{3}\left(P 1^{\alpha}+P 2^{\alpha}+P 3^{\alpha}\right)\right]^{\frac{1}{\alpha}}$

$\mathrm{P} 1=$ Probability of not surviving to age 40

P2 = Adult illiteracy rate

P3 = Unweighted average of population not using an improved water source and children underweight for age $\alpha=3$

A country's HPI score equals the proportion of its population affected by any one of these deprivations, providing a comparative measure for the prevalence of deprivation.

Subramanian (McGillivray 2007) notes that income-based measures of poverty are often poor proxies for a capabilities-based definition of deprivation and disparity,

\footnotetext{
1.In 2001, the Human Development Report Office of the UNDP changed the formula used to calculate the HPI by dropping the indicator 'access to health service'. used to calculate the HPI by drepice'. This change in the formula made longitudinal analysis of the HPI that included both data recorded prior to and after 2001 difficult, if not fatally suspect. For the purposes of this study, the HPI has been recalculated for each of the countries included in the analysis between the years 1990 and 2010, using the formula described above.
} 
pointing to China, Costa Rica, Kenya, Peru and the Philippines, 'which have displayed greater success in reducing human poverty than income-poverty'. The experience of these countries points 'to the possibilities of enhancing achievements in the space of human functionings by routes different from those centered exclusively on income growth and the percolation of that growth to the poor' (Subramanian in McGillivray 2007).

\section{Data and methodology}

This study focuses on the outcomes of a panel data set (created for the purpose of this study) of HPI scores for a set of 47 subSaharan African countries, between 1990 and 2010 (calculated using the formula above with current data), and a range of indicators that the development literature and theory suggest should have an effect on poverty. Several models have been created to empirically test the relationship between both the HPI and household consumption expenditure and indicators relating to economic growth-based and capabilities-based approaches to development.

Data for this study have been compiled from a range of international development databases, including the World Bank's World Development Indicators, the World Bank's Privatization Database, the Penn World Table, the World Health Organization, the Millennium Development Goals and the International Monetary Fund's International Financial Indicators.

\section{Estimation model}

This article analyses the effects of economic growth and human capabilities-based policies on deprivation, as measured by the HPI, focusing on the primary research question: what is the effect of these policies and interventions on the HPI for selected developing countries? To examine this question, a panel regression model is applied to measure changes in the HPI between 1990 and 2010 for sub-Saharan African countries.

In each model, the dependent variable is either the HPI or household final consumption expenditure per capita. In the economic growth models, the key explanatory variable of interest is GDP per capita, measured in constant international dollars. In the capabilities models, the key explanatory variable of interest is per capita total public expenditure on health, measured in purchasing power parity international dollars. Covariates are included in each model to control for other factors that may drive change in the HPI or household consumption expenditure.

The estimated models are fixed effects models, which control for country-specific unobservable determinants of multidimensional poverty and household consumption expenditure, significant concerns with panel datasets similar to the one that is used in this study. One limitation of using fixed effects estimators is that time-invariant variables, such as geographic characteristics, drop out of the models, making estimations of the coefficients for these variables impossible to determine. Instead, all of the effects of time-invariant factors are absorbed in the error term in fixed effects models. Random effects models are better suited to the use of timeinvariant variables. However, Wooldridge (2006) notes that fixed effects models are the more appropriate models when using panel data to determine policy effects over time.

\section{Dependent variables \\ Human Poverty Index}

The HPI, as noted by Anand and Sen (1997), is premised on the understanding of poverty as a multidimensional phenomenon; it was created to provide a fuller accounting of human deprivation than those based simply on some measure of income. The UNDP adopted it and promoted it as a tool for planning and advocacy, as well as a tool for research into changes in multidimensional poverty. Country HPI scores were reported annually in the UNDP's Human Development Report until 2010. The observation of annual changes in HPI scores invites inspection and analysis as to the factors behind them.

\section{Household final consumption expenditure per capita as a percent of gross domestic product}

A central question addressed in this study is whether or not there is a difference in those factors that reduce multidimensional poverty and those that reduce some monetary-based measure of poverty. The question then becomes: which monetary-based measure of poverty should be used? Coudouel, Hentschel and Wodon (2002) make the case, with regard to monetary-based measures of poverty, that consumption expenditure, rather than income, is a more appropriate measure of well-being. They note that consumption is a better outcome indicator, is more accurately measured and more closely reflects standard of living than income. Consistent with Coudouel et al. recommendation, I will use household final consumption per capita as the dependent variable against which I will compare findings from the HPI models.

\section{Independent variables}

The selection of variables for this study is intentionally focused on those that have some relationship to state policy decisions, rather than those that occur naturally (e.g. geography, natural disasters) or those that are more individual in nature (e.g. family size, wages). By focusing on variables that are the result of policy decisions, it is the aim of this report to suggest that state interventions and state policies have, perhaps, as important a role to play in reducing deprivation as do market and civil society actors.

\section{Economic growth-based variables}

Neoclassical economic theory, as well as neoliberal proponents of the Washington Consensus and its various permutations, suggests that opening up to imports and increasing exports, privatising state-owned enterprises or 
other government assets and implementing exchange rate controls, to name a few, should result in poverty reduction, as measured in GDP per capita and compared to specified poverty levels, as the economies of developing countries grow (Asian Development Bank 2004; Dollar \& Kraay 2003). However, whilst a developing country may have managed to increase its GDP per capita over a period of time, it does not necessarily follow that multidimensional poverty, as measured by the HPI, will have declined.

The first growth-based variable considered as a potential driver of the HPI was the broad measure of GDP per capita (Dollar \& Kraay 2003; Ferreira \& Ravallion 2008). As covariates I include variables for foreign direct investment (Asian Development Bank 2004; Spence 2008), a measure of exports as a percentage of GDP (Todaro \& Smith 2003; Zedillo, Messerlin \& Nielsen 2005), imports as a percentage of GDP (Castilho, Menendez \& Sztulman 2012), the official exchange rate and inflation (Baldacci et al. 2004). The inclusion of these last variables as covariates was based on the grounds that openness to trade and prescriptions for keeping inflation and exchange rates low have been central pieces of the toolkit of international financial institutions in recent decades.

\section{Capabilities-based variables}

Human development advocates, however, argue that poverty reduction is as much, if not more, a function of investments in human capability development as it is of economic growth policies. Proponents of capabilitiesbased development place human beings, instead of economies, at the centre of the development enterprise and would point to investments in, and policies that support, improved health care, education and social inclusion as likely to increase well-being and, therefore, address the multidimensional nature of poverty (Fukuda-Parr 2003; Kuklys 2005; Sen 1999).

This argument will be tested by estimating the effect on the HPI of a set of variables that could arguably serve as proxies for increased state-level investments in capabilities. The key indicator of interest is public health expenditure per capita, following Ranis's et al. (2006) findings that increased public sector investment in health is associated with improved human development and economic growth outcomes. The model includes as a covariate the female secondary school enrolment rate, following Lorentzen, McMillan and Wacziarg's (2005) findings of a significant and positive relationship between per capita income and post-secondary school enrolment rates. The model also includes a variable measuring the percentage of women in a given country's parliament, on the grounds that an increase in participation in national parliaments by women may be a proxy for social inclusion of women more broadly in society; what is being tested, by proxy, is the relationship between social inclusion of women and multidimensional poverty (Kabeer 1999).
In addition to these indicators, the labour force participation rate is included as a covariate on the grounds that employment is key to expanding capabilities and improvements in the ability to derive income from labour through employment may have an effect on multidimensional poverty, in addition to household consumption expenditure. To the extent that ownership of livestock assets is a key wealth indicator in many parts of the developing world, changes in livestock productivity may be related to components of the HPI and thus it is included as a covariate (Barrett, Carter \& Little 2006; Hoddinott, Rosegrant \& Torero 2012). I also include a measure of agricultural productivity as a covariate.

Conceptually, the models are intended to demonstrate that the HPI is responsive to specific policies adopted by, or conditions that exist in, individual countries.

This conceptual model may be presented as an equation:

$H P I_{\mathrm{it}}=f(z g, z c, t)+C_{\mathrm{i}}+E_{\mathrm{it}}$

[Eqn 2]

The HPI for country $i$ at time $t$ is explained as a function of $z g$, a vector of economic growth-based variables, $z c$, a vector of capabilities-based variables, and $t$. The model includes a set of indicators $\mathrm{C}_{i}$ representing the countries in the model. The variable time is key since it will show whether a change in policy contributes to a change in HPI, potentially providing the strongest evidence of 'cause'.

Table 1 also lists the 47 countries included in the analysis and provides means and standard errors for all variables.

Table 1 presents the mean HPI, GDP per capita, household consumption expenditure and health expenditure by country over the course of this study. Mean values range from, at the lower end, Mauritius, with a mean HPI of $11.4 \%$, to Niger, with a mean HPI of $62 \%$ over the 21-year period of this study. In terms of GDP per capita, amounts range from a high of approximately $\$ 10000$ per year in the Seychelles, to a low of approximately \$151 in Liberia and Ethiopia. With regard to mean household consumption expenditure per capita, amounts range from a high of \$2 855 in South Africa, to a low of approximately $\$ 120$ in the Democratic Republic of Congo. Finally, in terms of health expenditure per capita, amounts range from a low of $\$ 5.82$ in Somalia, to a high of $\$ 392$ in the Seychelles.

\section{Panel regression results Economic growth-based variables and household consumption expenditure}

Looking first at those variables meant to measure the effect of changes in indicators of economic growth on household consumption expenditure for all countries in the data set, displayed in Table 2, only GDP per capita behaves as predicted by the economic growth literature, with a $\$ 1$ increase associated with an approximately $\$ 0.50$ increase 
TABLE 1: Descriptive statistics.

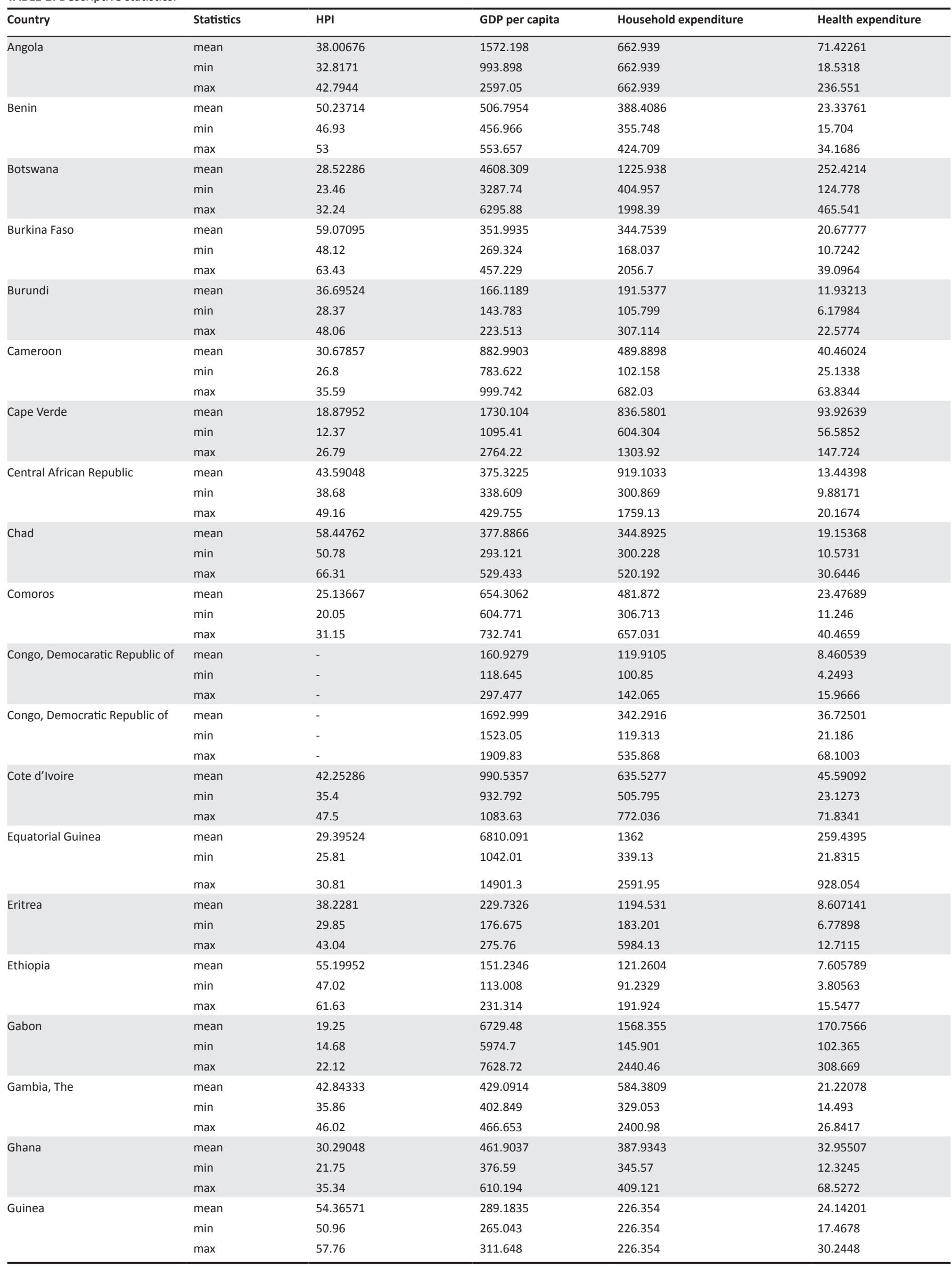


TABLE 1 (Continues...): Descriptive statistics.

\begin{tabular}{|c|c|c|c|c|c|}
\hline Country & Statistics & HPI & GDP per capita & Household expenditure & Health expenditure \\
\hline \multirow[t]{3}{*}{ Guinea-Bissau } & mean & 44.6319 & 456.529 & - & 22.57278 \\
\hline & $\min$ & 35.73 & 386.533 & - & 10.6159 \\
\hline & $\max$ & 52.84 & 589.765 & - & 38.2167 \\
\hline \multirow[t]{3}{*}{ Kenya } & mean & 29.22381 & 525.5078 & 379.8887 & 23.22798 \\
\hline & $\min$ & 27.9 & 495.569 & 344.137 & 14.0337 \\
\hline & $\max$ & 30.28 & 574.853 & 397.561 & 35.8385 \\
\hline \multirow[t]{3}{*}{ Lesotho } & mean & 27.17286 & 656.3164 & 709.3681 & 47.16788 \\
\hline & $\min$ & 17 & 510.689 & 414.636 & 22.5697 \\
\hline & $\max$ & 33.13 & 879.224 & 882.423 & 115.716 \\
\hline \multirow[t]{3}{*}{ Liberia } & mean & 41.59476 & 151.2246 & 514.5532 & 14.48995 \\
\hline & $\min$ & 35.15 & 50.0422 & 189.86 & 0 \\
\hline & $\max$ & 48.56 & 252.955 & 943.692 & 41.4482 \\
\hline \multirow[t]{3}{*}{ Madagascar } & mean & - & 283.3353 & 251.2773 & 11.16307 \\
\hline & $\min$ & - & 249.068 & 230.516 & 6.7362 \\
\hline & $\max$ & - & 328.417 & 326.965 & 17.4782 \\
\hline \multirow[t]{3}{*}{ Malawi } & mean & 36.64381 & 214.0624 & 212.7819 & 15.45903 \\
\hline & $\min$ & 29.84 & 179.906 & 186.648 & 7.13484 \\
\hline & $\max$ & 42.86 & 258.058 & 233.969 & 28.9889 \\
\hline \multirow[t]{3}{*}{ Mali } & mean & 58.25191 & 398.3281 & 309.589 & 24.64392 \\
\hline & $\min$ & 50.07 & 325.84 & 172.257 & 14.4131 \\
\hline & $\max$ & 64.22 & 498.475 & 370.284 & 41.179 \\
\hline \multirow[t]{3}{*}{ Mauritania } & mean & 40.14714 & 680.2131 & 428.9057 & 31.33392 \\
\hline & $\min$ & 33.86 & 614.603 & 296.752 & 19.5969 \\
\hline & $\max$ & 46.82 & 801.995 & 554.792 & 58.9098 \\
\hline \multirow[t]{3}{*}{ Mauritius } & mean & 11.42762 & 4458.069 & 2132.143 & 222.6586 \\
\hline & $\min$ & 8.73 & 3037.46 & 479.948 & 126.27 \\
\hline & $\max$ & 14.49 & 6320.51 & 3472.71 & 464.77 \\
\hline \multirow[t]{3}{*}{ Mozambique } & mean & 47.36429 & 257.3155 & 1114.347 & 16.56636 \\
\hline & $\min$ & 42.43 & 175.888 & 191.769 & 7.62147 \\
\hline & $\max$ & 52.91 & 380.849 & 4264.62 & 26.432 \\
\hline \multirow[t]{3}{*}{ Namibia } & mean & 21.81952 & 3226.933 & 1436.103 & 188.2075 \\
\hline & $\min$ & 19.54 & 2672.81 & 255.743 & 105.049 \\
\hline & $\max$ & 24.44 & 4073.83 & 2082 & 283.505 \\
\hline \multirow[t]{3}{*}{ Niger } & mean & 62.11286 & 267.2257 & 2127.638 & 10.92156 \\
\hline & $\min$ & 50.95 & 233.68 & 192.919 & 5.21647 \\
\hline & $\max$ & 68.44 & 302.852 & 2809.95 & 19.4509 \\
\hline \multirow[t]{3}{*}{ Nigeria } & mean & 40.47286 & 739.474 & - & 48.73779 \\
\hline & $\min$ & 39.18 & 660.179 & - & 16.1294 \\
\hline & $\max$ & 42.43 & 972.546 & - & 87.6313 \\
\hline \multirow[t]{3}{*}{ Rwanda } & mean & 35.81857 & 249.5331 & 216.2174 & 21.99299 \\
\hline & $\min$ & 26.23 & 140.254 & 188.669 & 8.05469 \\
\hline & $\max$ & 53.9 & 352.412 & 240.447 & 55.224 \\
\hline \multirow[t]{3}{*}{ Sao Tome and Principe } & mean & 19.58524 & 749.9515 & 295.6844 & 67.08189 \\
\hline & $\min$ & 15.57 & 693.966 & 265.834 & 37.2379 \\
\hline & $\max$ & 25.32 & 812.639 & 331.688 & 100.633 \\
\hline \multirow[t]{3}{*}{ Senegal } & mean & 44.51143 & 710.8468 & 542.2704 & 37.44858 \\
\hline & $\min$ & 34.53 & 634.352 & 505.047 & 21.3195 \\
\hline & $\max$ & 51.08 & 796.149 & 585.274 & 65.7465 \\
\hline Seychelles & mean & - & 10721.06 & 644.745 & 392.6027 \\
\hline & $\min$ & - & 8559.97 & 619.813 & 297.824 \\
\hline & $\max$ & - & 13019.6 & 699.444 & 458.138 \\
\hline Sierra Leone & mean & 52.12286 & 313.0867 & 249.1474 & 39.82663 \\
\hline & $\min$ & 44.94 & 247.121 & 197.463 & 19.5077 \\
\hline & $\max$ & 55.09 & 373.677 & 294.565 & 72.2793 \\
\hline Somalia & mean & - & - & 314.6906 & 5.828213 \\
\hline & $\min$ & - & - & 281.971 & 3.86027 \\
\hline & $\max$ & - & - & 335.983 & 7.43116 \\
\hline South Africa & mean & 19.77381 & 4946.413 & 2855.047 & 356.5637 \\
\hline & $\min$ & 15.98 & 4472.49 & 2621.24 & 205.277 \\
\hline & $\max$ & 22.76 & 5848.04 & 3300.92 & 630.926 \\
\hline
\end{tabular}


TABLE 1 (Continues...): Descriptive statistics.

\begin{tabular}{|c|c|c|c|c|c|}
\hline Country & Statistics & HPI & GDP per capita & Household expenditure & Health expenditure \\
\hline \multirow[t]{2}{*}{ Sudan } & mean & 32.8081 & 594.8488 & 1201.169 & 36.96776 \\
\hline & $\min$ & 28.83 & 438.777 & 390.314 & 11.4749 \\
\hline \multirow[t]{3}{*}{ Swaziland } & mean & 31.53429 & 2213.391 & 1179.599 & 128.1826 \\
\hline & $\min$ & 29.16 & 1995.8 & 503.534 & 58.3248 \\
\hline & $\max$ & 35.57 & 2450.83 & 1727.94 & 242.682 \\
\hline \multirow{2}{*}{ Tanzania } & $\min$ & - & 278.426 & 170.297 & 6.28221 \\
\hline & $\max$ & - & 451.547 & 2124.77 & 36.759 \\
\hline \multirow[t]{3}{*}{ Togo } & mean & 36.66714 & 393.398 & 375.0566 & 22.57624 \\
\hline & $\min$ & 33.27 & 319.663 & 261.146 & 13.937 \\
\hline & $\max$ & 38.03 & 447.232 & 466.035 & 39.1102 \\
\hline \multirow[t]{2}{*}{ Uganda } & mean & 33.46095 & 279.4554 & 234.0452 & 24.65818 \\
\hline & $\min$ & 24.07 & 197.64 & 169.487 & 14.7793 \\
\hline \multirow[t]{3}{*}{ Zambia } & mean & 37.19667 & 622.3303 & 322.1719 & 36.90014 \\
\hline & $\min$ & 33.19 & 557.147 & 234.957 & 17.9974 \\
\hline & $\max$ & 40.31 & 741.442 & 420.153 & 73.8443 \\
\hline \multirow[t]{3}{*}{ Zimbabwe } & mean & 32.20048 & 577.3773 & 453.202 & 71.83667 \\
\hline & $\min$ & 22.6 & 344.742 & 325.848 & 35.7119 \\
\hline & $\max$ & 38.95 & 718.418 & 529.441 & 98.8542 \\
\hline \multirow[t]{3}{*}{ Total } & mean & 37.50327 & 1405.364 & 730.4627 & 67.07606 \\
\hline & $\min$ & 8.73 & 50.0422 & 91.2329 & 0 \\
\hline & $\max$ & 68.44 & 14901.3 & 5984.13 & 928.054 \\
\hline
\end{tabular}

HPI, Human Poverty Index; GDP, gross domestic product.

TABLE 2: Economic growth models.

\begin{tabular}{|c|c|c|}
\hline Variable & $\begin{array}{l}\text { Household consumption } \\
\text { expenditure }\end{array}$ & HPI \\
\hline \multirow[t]{2}{*}{ GDP per capita } & $0.497 \dagger$ & -0.000268 \\
\hline & $(-0.146)$ & $(-0.000287)$ \\
\hline \multirow[t]{2}{*}{ Inflation } & 2.709 & $0.00246 \dagger$ \\
\hline & $(-2.527)$ & $(-0.000664)$ \\
\hline \multirow[t]{2}{*}{ FDI } & -6.499 & -0.024 \\
\hline & $(-10.16)$ & $(-0.0246)$ \\
\hline \multirow[t]{2}{*}{ Exports } & -0.0627 & -0.0426 \\
\hline & $(-8.888)$ & $(-0.0507)$ \\
\hline \multirow[t]{2}{*}{ Imports } & 4.729 & -0.0171 \\
\hline & $(-5.416)$ & $(-0.0308)$ \\
\hline \multirow[t]{2}{*}{ Official exchange rate } & -0.0773 & -0.00098 \\
\hline & $(-0.131)$ & $(-0.00115)$ \\
\hline \multirow[t]{2}{*}{ Constant } & -165.4 & $40.65 \dagger$ \\
\hline & $(-225)$ & $(-1.629)$ \\
\hline Observations & 637 & 821 \\
\hline$R$-squared & 0.09 & 0.051 \\
\hline Number of countries & 43 & 41 \\
\hline
\end{tabular}

$(p<0.01)$ in household consumption expenditure. None of the other indicators is statistically significant.

\section{Economic growth-based variables and the Human Poverty Index}

Table 2 also presents the results of a panel regression model that regresses the HPI on the same economic growth indicators. Amongst these indicators, only the rate of inflation is statistically significant, with a $1 \%$ increase resulting in a modest $0.0025(p<0.01)$ increase in the HPI. None of the other indicators is statistically significant.
TABLE 3: Capabilities models.

\begin{tabular}{|c|c|c|}
\hline Variable & $\begin{array}{c}\text { Household consumption } \\
\text { expenditure }\end{array}$ & HPI \\
\hline \multirow[t]{2}{*}{ Food production index } & -1.358 & $-0.0489 \ddagger$ \\
\hline & $(-0.897)$ & $(-0.0188)$ \\
\hline \multirow[t]{2}{*}{ Livestock production index } & 1.557 & $-0.0520 \%$ \\
\hline & $(-1.576)$ & $(-0.022)$ \\
\hline \multirow[t]{2}{*}{ Labour force participation rate } & 13.18 & -0.301 \\
\hline & $(-9.181)$ & $(-0.196)$ \\
\hline \multirow{2}{*}{$\begin{array}{l}\text { Percentage of women in } \\
\text { parliament }\end{array}$} & -1.625 & $-0.134 \dagger$ \\
\hline & $(-1.705)$ & $(-0.0425)$ \\
\hline \multirow{2}{*}{$\begin{array}{l}\text { Secondary school enrolment } \\
\text { (female) }\end{array}$} & 4.041 & -0.0629 \\
\hline & $(-4.275)$ & $(-0.0707)$ \\
\hline \multirow{2}{*}{$\begin{array}{l}\text { Health expenditure per } \\
\text { capita (current US dollars) }\end{array}$} & $1.234 \dagger$ & $0.0119 \neq$ \\
\hline & $(-0.356)$ & $(-0.00476)$ \\
\hline \multirow[t]{2}{*}{ Constant } & -390.3 & $69.97 \dagger$ \\
\hline & -681.5 & -13.88 \\
\hline Observations & 244 & 311 \\
\hline Number of country & 33 & 38 \\
\hline$R$-squared (within) & 0.46 & 0.531 \\
\hline
\end{tabular}

\section{Capabilities-based variables and household consumption expenditure}

Table 3 presents the results of the panel regressions of the HPI and household consumption expenditure on the capabilities-based variables. Using the fixed effects estimator and regressing household consumption expenditure on the set of capabilities-based variables for all countries in the data set finds none of the variables to be statistically significant. 


\section{Capabilities-based variables and the Human Poverty Index}

However, when the HPI is considered, several of the indicators are found to be associated with significant reductions in multidimensional poverty. As shown in Table 3, a one unit increase in both the food production index and livestock production index are associated with a $0.05 \%$ reduction in the HPI $(p<0.05)$; each percentage increase in percentage of parliamentary seats held by women is associated with a $0.13 \%$ reduction in the HPI $(p<0.01)$. Curiously, neither the labour force participation rate nor the secondary school enrolment rate amongst girls is statistically significant and an increase in health expenditure per capita is associated with a statistically significant $(p<0.05)$, but economically insignificant, $0.005 \%$ increase in the HPI.

Although small, the relationship between health expenditure per capita and the HPI is anomalous. One possible explanation for this outcome is that the indicator, health expenditure per capita, measures total health expenditure, public and private, and covers the provision of preventative and curative health services, family planning and emergency aid, but not expenditure on water improvement and sanitation (and is assumed to be unrelated to adult illiteracy). Given that access to an improved water source is a principle component of the $\mathrm{HPI}$, and given that water-borne illnesses disproportionately affect the most deprived, it may be the case that increases in total health care expenditure come at the expense of investments in improving water and sanitation. Such a zerosum outcome may account for the positive and significant relationship between total health care expenditure and marginal increases in the HPI, but further analysis of this relationship falls beyond the scope of this study.

\section{Conclusion}

From the outset, the intent of this study has been to determine whether those factors that drive change in an income-based metric of poverty are the same as or different from those that drive change in a multidimensional metric. This is important because, presumably, policy and investment decisions are made based on the evidence of what does and does not work.

Despite claims to have moved into a 'post-Washington Consensus', neoliberal assumptions persist when it comes to policymaking amongst international finance institutions (IFIs) and many bilateral aid agencies; investments in, and loans to, developing countries should be targeted towards economic growth and the resulting wealth will trickle down to the poor, so the argument goes. However, continuing to conceptualise poverty as a function of income, whether national or individual, presents a misleading picture of the effect that development policy has had on the well-being of the poorest.

One example of the persistence of neoliberal influence over development policy can be found in a recent World Bank Independent Evaluation Group (IEG) report on the role and effectiveness of the World Bank's International Finance Corporation (IFC) in terms of poverty reduction. The executive summary of the report, which found the
IFC's poverty reduction outcomes lacking, begins with the statement "growth is good for the poor," echoing Dollar and Kraay (2003) and, implicitly, ignoring research that argues for directly investing in the well-being of the poor. In fact, the evaluation of the IFC's efforts between 2000 and 2010 contained a candid admission that:

(IFC) projects are designed to contribute to growth and therefore may have poverty effects. However, it has been challenging for IFC to incorporate distributional issues in interventions. Fewer than half of projects reviewed included evidence of poverty and distributional aspects in project objectives, targeting of interventions, characteristics of intended beneficiaries, or tracking of impacts. (IEG 2011, emphasis added)

Why is this statement by the IEG important? IFC investments dwarf those made by its traditional lending instruments, the International Bank for Reconstruction and Development and International Development Association: the Bretton Woods Project (2014) reports that between July 2009 and June 2013 IFC investment in financial intermediaries (largely banking and private equity firms) totalled approximately $\$ 36$ billion, or more than three times the amount the rest of the World Bank Group invested in education and 50\% more than it invested in health care. Arguably, investments of this magnitude exert a strong influence over national development policy.

Critics of development policy, as promoted by Western bilateral aid agencies and IFIs, note that investments in the developing world proceed on the assumption that growth benefits the rich and poor alike, despite scant evidence supporting this assumption. This study begins from a similar premise and concludes with a similar finding; there are no findings supporting the hypothesis that as a subSaharan nation becomes wealthier, in terms of GDP per capita, deprivation is reduced. However, this study finds evidence suggesting that direct investments in livestock and agricultural productivity, and in the social inclusion of women, may reduce multidimensional poverty. These findings support Ranis et al.'s (2006) findings that poverty reduction and sustained economic growth typically occur when investments are first made directly in human development, rather than in economic growth strategies.

Dollar and Kraay (2003) famously reported that growthenhancing policies and institutions 'tend to benefit the poor and everyone else in society - equiproportionately', and that 'pro-poor' policy interventions, such as those related to primary school attainment, public expenditure on health and education and labour productivity in agriculture, have little to no effect in terms of raising the share of income for the poorest. The findings from this study confirm that economic growth, as measured by GDP per capita, does tend to benefit households, as measured by household consumption expenditure, although not on the 1:1 ratio claimed in Dollar and Kraay's examination of income poverty of the poorest quintile.

However, a closer look at drivers of multidimensional poverty in sub-Saharan Africa would suggest that, in fact, deprivation is considerably reduced by factors other than 
economic growth, including increases in food production, livestock production and the percentage of women in national parliaments, which may be a proxy for social inclusion and gender equity.

The primary aim of this study has been to identify from amongst the range of potential macro-level drivers those that have an influence on multidimensional poverty. It has as its starting point the premise that poverty is a multidimensional phenomenon and, as a corollary premise, a better understanding of what drives change in a particular multidimensional index - the HPI - would help to shape policies designed to improve well-being, as measured in terms other than monetary.

Growth, as measured by increases in GDP per capita, is not, it would seem, an unalloyed good for the poor, as Dollar and Kraay (2003) argue, if one measures poverty not by lowness of income, but by a multidimensional metric that more closely reflects deprivation. As Stiglitz, Sen and Fittousi (2009) caution, if the metrics used in measuring poverty are wrong, then so, too, will be the inference that we draw about what makes for good policy. From the findings presented above, it would seem that the inferences will vary widely if, rather than an income-based metric, one uses a multidimensional metric to measure poverty.

\section{Acknowledgements Competing interests}

I declare that I have no financial or personal relationship(s) that may have inappropriately influenced me in writing this article.

\section{References}

Alkire, S. \& Foster, J., 2011, 'Understandings and misunderstandings of multidimensional poverty measurement', OPHI working paper no. 3, Oxford Poverty and Human Development Initiative, University of Oxford, Oxford.

Alkire, S. \& Santos, E., 2009, 'Poverty and inequality measurement', in S. Denuelin \& L. Shahani (eds.), An introduction to the human development and capability approach: Freedom and agency, pp. 3-21, Earthcan, London.

Anand, S., Segal, P. \& Stiglitz, J., 2010, Debates on the measurement of global poverty, Oxford Scholarship Online May. Available from http://www.oxfordschloarship.com

Anand, S. \& Sen, A., 1997, 'Contents of human development and poverty: A multidimensional perspective', Human Development Papers, United Nations Development Program, New York, NY.

Arimah, B.C., 2004, 'Poverty reduction and human development in Africa', Journal of Human Development 5(3), pp. 399-415. http://dx.doi. org/10.1080/1464988042000277260

Asian Development Bank \& Japan International Cooperation Agency, 2004, Economic growth and poverty reduction in Bangladesh, Asian Development Bank, Bangladesh Resident Mission \& Embassy of Japan in Bangladesh, Taishikan, Bangladesh.

Atkinson, A.B., 1987, 'On the measurement of poverty', Econometrica 55(4), 794-764. http://dx.doi.org/10.2307/1911028

Baldacci, E., Clements, B., Gupta, S. \& Cui, Q., 2004, 'Social spending, human capital, and growth in developing countries: Implications for achieving the MDGs', IMF working paper no. 04217, International Monetary Fund, Washington, DC.
Barrett, C.B., Carter, M.R. \& Little, P.D., 2006, 'Understanding and reducing persistent poverty in Africa: Introduction to a special issue', Journal of Development Studies 42(2), 167-177. http://dx.doi.org/10.1080/00220380500404587

Basarir, H., 2011, 'Poor, multidimensionally speaking: Evidence from South Africa' Journal of African Economies 20(3), 463-504. http://dx.doi.org/10.1093/jae/ejr001

Berenger, V. \& Verdier-Chouchane, A., 2007, 'Multidimensional measures of wellbeing: Standard of living and quality of life across countries', World Development 35(7), 1259-1276. http://dx.doi.org/10.1016/j.worlddev.2006.10.011

Bretton Woods Project, 2014, Follow the money: The World Bank Group and the use of financial intermediaries', Bretton Woods Project, London.

Castilho, M., Menendez, M. \& Sztulman, A., 2012, 'Trade liberalization, inequality and trade in Brazilian states', World Development 40(4), 821-835. http://dx.doi. org/10.1016/j.worlddev.2011.09.018

Coudouel, A., Hentschel, J. \& Wodon, Q., 2002, 'Poverty measurement and analysis', in World Bank, PRSP Sourcebook, World Bank, Washington, DC.

Dasgupta, P. 1993, An inquiry into well-being and destitution, Oxford University Press, New York, NY.

Dollar, D. \& Kraay, A., 2003, 'Growth is good for the poor', World Bank policy research working paper no. 2587, World Bank, Washington, DC.

Ferreira, F.H.G. \& Ravallion, M., 2008, 'Global poverty and inequality: A review of the evidence', World Bank Development Research Group Poverty Team, policy research working paper no. 4623, World Bank, Washington, DC.

Fleurbaey, M., 2009, 'Beyond the GDP: The quest for a measure of social welfare', Journa of Economic Literature 47(4), 1029-1075. http://dx.doi.org/10.1257/jel.47.4.1029

Fukuda-Parr, S., 2003, 'The human development paradigm: Operationalizing Sen's ideas on human capabilities', Feminist Economics 9(2-3), 301-317.

Hoddinott, J., Rosegrant, M. \& Torero, M., 2012, 'Investments to reduce hunger and undernutrition', International Food Policy Research Institute, Washington, DC.

Independent Evaluation Group, 2011, Assessing International Finance Corporation's (IFC) poverty focus and results, The World Bank, Washington, DC.

Jolly, R., 2003, 'Human development and neoliberalism, paradigms compared', in S. Fukuda-Parr \& A.K. Shiva Kumar (eds.), Readings in human development: Concepts, measures and policies for a development paradigm, pp. 89-92, Oxford University Press, New Delhi.

Kabeer, N., 1999, 'Resources, agency and achievements: Reflections on the measurement of women's empowerment', Development and Change 30, 435-464.

Kakwani, N. \& Silber, J. (ed.), 2008, Quantitative approaches to multidimensional poverty, Palgrave-MacMillan, Houndmills. http://dx.doi.org/10.1057/9780230582354

Kuklys, W., 2005, Amartya Sen's capability approach: Theoretical insights and empirical applications, Springer, Berlin, Germany.

Lorentzen, P., McMillan, J. \& Wacziarg, R., 2005, 'Death and development', working paper 11620, National Bureau of Economic Research, Cambridge, MA.

McGillivray, M. (ed.), 2007, Human well-being: Concept and measurement, Palgrave Macmillan, Basingstoke.

Ranis, G., Stewart, F. \& Samman, E., 2006, 'Human development: Beyond the Human Development Index', Journal of Human Development 7(3), 324-358. http://dx.doi. org/10.1080/14649880600815917

Ravallion, M., 1992, 'Poverty comparisons: A guide to concepts and methods', Living Standards Measurement Study working paper no. 88., World Bank, Washington DC.

Sen, A., 1999, Development as freedom, Oxford University Press, Oxford.

Spence, M., 2008, The growth report: Strategies for sustained growth and inclusive development, Commission on Growth and Development, International Bank for Reconstruction and Development, World Bank, Washington, DC.

Stiglitz, J., Sen, A. \& Fitoussi, J.-P., 2009, Report by the Commission on the Measurement of Economic Performance and Progress, Commission on the Measurement of Economic Performance and Social Progress, Paris, France.

Thorbecke, E., 2008, 'Multidimensional poverty: Conceptual and measurement issues', in N. Kakwani \& J. Silber (eds.), The many dimensions of poverty, Palgrave MacMillan, New York, NY

Todaro, M.P. \& Smith, S.C., 2003, Economic development, 8th edn., Addison Wesley, Boston, MA.

UI Haq, M., 1995, Reflections on human development, Oxford University Press, New York, NY.

UNDP, 1997, Human Development Report, Oxford University Press, New York, NY.

UNDP, 2008, Human development indices: A statistical update 2008, Oxford University Press, New York, NY.

Wooldridge, J.M., 2006, Introductory econometrics: A modern approach, 3rd edn., Thomson Southwestern, Mason, $\mathrm{OH}$.

Zedillo, E., Messerlin, P. \& Nielsen, J., 2005, 'Trade for development', United Nations Millennium Project Task Force on Trade, Earthscan, Sterling, VA. 